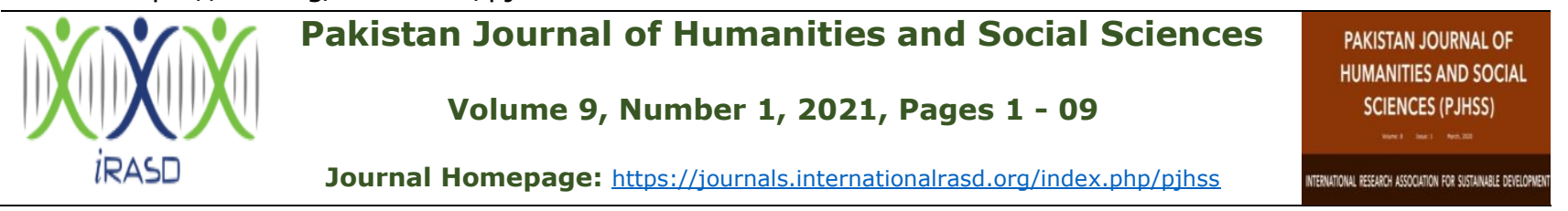

\title{
Unemployment and Monetary Policy Dynamics in Pakistan: Evidence from Cointegration Analysis
}

Dr. Hina Ali ${ }^{1}$, Muhammad Zeeshan Ali ${ }^{2}$, Farhana Nosheen ${ }^{3}$, Afifa Sadar Ud Din ${ }^{4}$

${ }^{1}$ Assistant Professor, Department of Economics, The Women University, Multan Pakistan

2 MSc Management with Finance, University of Chaster England

3 Assistant Professor, Department of Economics, Govt Associate College for Women Muzaffarabad, Multan, Pakistan

${ }^{4}$ MPhil Scholar, Department of Economics, The Women University, Multan

\section{ARTICLE INFO}

Article History:

Received:May 28, 2021

Revised: June 26, 2021

Accepted: June 28, 2021

Available Online: June 30, 2021

\section{Keywords:}

Unemployment

Bank credit to the private sector

Budget deficit

Population growth

\section{JEL Classification Codes:}

E24, E51, H62, H63, P42

\section{ABSTRACT}

\begin{abstract}
This study examined the impact of monetary policy on unemployment in Pakistan. The time-series data for 1977 to 2019 was taken and the ARDL technique is used for estimation. Unemployment was used as a dependent variable along with other control variables while the money supply was the core independent variable of the research. It was concluded that money related arrangement not just contributes to observing past patterns and additionally future projections of superficial factors of real factors also. The outcomes show that there is a critical and negative connection between spending Deficit and unemployment. The gross domestic product development rate is decidedly identified with unemployment. Populace development rate is adversely identified with unemployment. The consumer price index is contrarily identified with unemployment.
\end{abstract}

(C) 2020 The Authors, Published by iRASD. This is an Open Access Article under the Creative Common Attribution Non-Commercial 4.0

Corresponding Author's Email: hinaali@wum.edu.pk

\section{Introduction}

The State Bank of Pakistan is in charge of formulating and implementing monetary policy in Pakistan (SBP). Monetary policy influences aggregate demand in conjunction with fiscal and other related policies to promote noninflationary, long-term growth. Depending on the state of aggregate demand, the economy can operate at any national income and employment level (within the production frontier). Unemployment is the outcome of insufficient aggregate demand, while inflation is the product of excess demand (Hanif 2014).

Unemployment is one of the most important indicators of an economy's health. People are not earning following their ambition and abilities, as seen by a rising unemployment rate. Unemployment has a lot of different definitions. "Unemployment is assessed annually as a proportion of the labor force that cannot find work," according to the IMF (1998). From a social and economic standpoint, unemployment is not a good indicator for a country. Poverty, criminality, and political and social upheaval are all consequences. As a result, it is critical to address this topic in-depth and comprehend the variables that contribute to unemployment (Adil et al. 2014).

The International Labor Office reported at the height of the global crisis, which began in 2008, that global unemployment had hit its all-time high. In 2009, about 200 million people were seeking work, accounting for $7 \%$ of the worldwide workforce (imf.org). According to an estimated that by the year 2010 the world population had moved to 7 billion. As a result, there will be a greater increase in the mobility of labor from rural areas to urban areas, particularly in the big cities of the world. It has been projected that the population of big cities of the LCDs will treble in the year 2000. It is also because of the higher birth rates in the urban areas, and the rising mobility of rural to urban areas, as the agricultural labor has no way out after cultivation of all the lands and application of capital-intensive technologies on farms, except to rush to the urban trade and industrial centers where there is already a shortage of employment opportunities. In 1982 Karachi had a population of 5 million which rose to 7.5 million in 1992 and its projection for the year 2015 is 20.6 million; Bombay had a population 
of 15.1 million in 1995 which will go to 27.4 million in 2015; Tokyo had a population of Shanghai will rise from 15.1 million to 23.4 million during the same period. Such all is attributed to the greater migration of villagers to cities. The population of New York will move to 17.6 million in 2015 from 16.3 million in 1995.

\section{Literature Review}

Diaye and Laxton (2002) exclaimed that by the implementation of imperfect measures of credibility which were drawn from the long-term bond, one can find a relatively more accurate statistical model regarding inflation and unemployment as compared to other models, such as, constant parameter reduced form models which establish a stable relationship between past inflation and expected inflation. And threw light upon the advantages of adopting the real-time-outdo sample forecasting technique, and also showed that fitting historical Phillips curves would be difficult, and found many other helpful extensions: Firstly, the inclusion of exchange rates and short-run interest rates as measures would be useful to enhance systematic activity. Secondly, in process of monetary policy implementation, some time-variation should be allowed. Thirdly, in the United Kingdom, indexed bond markets should be developed to enhance monetary policy credibility. Finally, it was found that nonlinear trends in the unemployment-inflation process should be allowed to deal with capacity constraints.

Djivre and Ribon (2003) examined in their research paper that monetary policy affects the Israeli economy. Particularly focused on unemployment and rise in prices as key variables using data for 1990 and 1999, and used SVAR methodology for this purpose. researchers presented two models, in the first model, it was implied that changes in aggregate demand of an economy did not immediately affect its aggregate supply. Whereas, in the second model, it was implied that demand shocks had a maximum effect on the aggregate supply of the economy. These findings were different from those of large, closed economies, where prices respond with a time lag to monetary policy changes, and as a result, output response would be lagging. When actual structural shocks were analyzed, then it had come to the knowledge that the basic reason behind deviation of unemployment from its long-term value was the supply shocks. It was inferred that a model with nominal frictions was more appropriate for explaining the Israeli economy.

Abbritti et al. (2006) presented a dynamic general equilibrium model with hiring costs which proposed involuntary and cyclical unemployment in a steady-state as well as in the form of fluctuations. By using simulation techniques, the model with labor market imperfections performed better than the standard NK model due to the continuity of responses to sudden monetary changes. Furthermore, the model can be easily implemented to examine the effect of various market imperfections on both the steady-state and dynamic situation of the economy. With help of such a model, also explained how two economies, having different extents of imperfections, responded to policy or non-policy changes, and argued that a rigid economy used to be less inflammatory as compared to a flexible economy by giving examples of the experience of United States as a flexible economy and Europe as a rigid economy.

Epstein (2007) stated that different countries like Argentina, China, and India where central banks were using a huge number of instruments to control and administer their economies for the goal of development. And argued that such inflation-focused monetary policy had a serious effect on the entire macroeconomic policy apparatus. Results concluded that PERI/Bilkent project on alternatives to inflation targeting and PERI's UNDP work on South Africa had prepared a sequence of "real targeting" approaches to Central Banking which was ascertained as broad alternatives to inflation targeting and it worked as a developmental and stabilization factor for Central Banks.

Galbraith et al. (2007) found in their study that by using a VAR model of the American economy from 1984 to 2003. But Federal Reserve responded to the "real" signal of unemployment in such a way that the basic force behind the monetary policy was the fear of full employment in the economy. Applied tests of variations along with Taylor Rule, using dummy variables regression models, and using data back to 1969 and suggested that after 1983, Federal Reserve stopped responding to high inflation and high unemployment but started responding when unemployment declined "too low". Further found that monetary 
policy had a reasonable effect on wage inequality, and wage inequality was such a perspective where Federal Reserve takes off its whole responsibility. More specifically, it was questioned that whether information consisted in the structure of interest rates extend beyond inflation and unemployment to a measure of inequality in wages? The answer was given that yes! It does.

Berentsen et al. (2008) developed a theory in which models of both, goods market and labor market, were estimated by using the search-and-bargaining approach. According to the study, such a framework was manageable and only with aid of shifting the curves, many conclusions may be drawn, at least for equilibrium situations. This framework was also persuadable to numerical analysis that to what extent monetary policy, being only force, can become the reason for unemployment behavior, and the answer was that it can be. It was understood that besides monetary policy, there were still many other factors responsible for unemployment in the economy, for example, demographic aspects, productivity constraints, fiscal policy and energy prices.

Gocer (2013) analyzed the relationship between total credit volume of the banking sector and unemployment in fourteen selected European Union countries for the period of 1980-2012 using panel data analysis method that took into consideration structural breaks and cross-section dependence. Result of the analysis, it had been determined that credit increased had been reducing effect on the unemployment rate in European Union countries.

Ahmad (2013) examined the effect of prices on unemployment in Pakistan and used monthly data from January 1991 to December 2010. There were 238 observations in the model and found that with an increase in price level inflation rate also increased while inflation was negatively related to unemployment. In this way, there was an indirect relationship between CPI and unemployment. Umair and Ullah (2013) analyzed the relationship between GDP, inflation and unemployment in Pakistan, by taking data from 2000 to 2010 of secondary type and concluded that correlation between GDP and unemployment rate had also been found insignificant with a value of 0.196. It was, therefore, concluded that inflation had an influential role but for GDP and unemployment there was a positive relationship with insignificant levels in macroeconomics factors of the Pakistani economy.

Khurshid (2014) examined most developing countries were furnished with problems like mismanagement, unskilled and inexperienced labor force and political unrest despite having enough resources. And said that political disturbance in the developing country had effects on working and efficiency of central banks which further affected the effectiveness of monetary policy in that country. Outcomes claimed that various factors matter the working of monetary policy other than political perspective, for example, energy crisis, high inflation, corruption and terrorism, etc. Suggested some measures put the economy back on the path of economic development.

Mahmood, Waheed and Khalid (2017) checked long run relationship in monetary variables and gross domestic product in Pakistan by using annual data from 1983 to 2013, and to ascertain long run affiliation in monetary policy and growth Co-integration (Johansen cointegration) and for short run vector error correction model was employed. And the result showed that GDP was positively correlated with $M 2$, inflation and government spending. Investment prospects raised in the nation, as well as currency appreciation it had an optimistic effect on development. The money supply increased because of government borrowing from the State Bank of Pakistan for development objectives, it initially affected growth and later demonstrated influence on inflation. A low level of interest rate helped investors to invest along with result job opportunities will increase in the country.

Ahmad and Khan (2018) investigated that youth unemployment was a very important issue in Pakistan and explored factors of youth unemployment by taking data from 1991 to 2016 of Pakistan. Unemployment was reliant on variables while population, foreign direct investment, inflation, wage rate and government expenditure were used as independent variables. The Applied Ordinary Least Square method fully modified the least square and Robust least square, and outcomes revealed that there was a substantial influence of FDI, inflation and government spending on unemployment in Pakistan. But wage and population growth did not indicate a significant linkage with unemployment. 


\section{Data Sources and Methodology}

This study utilized the annual data from 1977 to 2019 for empirical estimations. The study focused on the estimation of the influence of monetary policy on inflation and unemployment, in Pakistan. Based on the time series characteristics of the data the Stationarity of the series has been checked by the ADF test then the existence of cointegration has been checked Bond test among the time series variables. Furthermore, ARDL has been employed by the researcher to check the short term and long-term association among the variables.

\section{Table 1: Description of Variables and unit of Measurement}

\begin{tabular}{|c|c|c|c|}
\hline Variables & Description & Unit of Measurement & $\begin{array}{l}\text { Expected } \\
\text { Signs }\end{array}$ \\
\hline $\begin{array}{l}\text { Unemployment } \\
\text { rate }\end{array}$ & $\begin{array}{l}\text { The unemployment rate is defined as the percentage } \\
\text { of the total labor force that is unemployed. }\end{array}$ & & \\
\hline $\begin{array}{l}\text { Bank Credit to } \\
\text { Private Sector }\end{array}$ & $\begin{array}{l}\text { Bank credit to the private sector consists of lending the } \\
\text { private sector through buying govt. securities, } \\
\text { credit rationing, loaning, etc. }\end{array}$ & Percent & - \\
\hline Exchange Rate & $\begin{array}{l}\text { The exchange rate is the value of the foreign currency in } \\
\text { terms of domestic currency }\end{array}$ & Percent & - \\
\hline $\begin{array}{l}\text { Growth rate of } \\
\text { Money Supply }\end{array}$ & $\begin{array}{l}\text { Money supply includes currency notes, coins, time } \\
\text { deposits and saving deposits, etc. Money supply } \\
\text { consists of all monetary aggregates. }\end{array}$ & Percent & - \\
\hline Budget Deficit & $\begin{array}{l}\text { The budget deficit is the quantity by which govt. } \\
\text { spending goes above or down its aggregate income. }\end{array}$ & Percent & - \\
\hline $\begin{array}{l}\text { Growth rate of } \\
\text { GDP }\end{array}$ & $\begin{array}{l}\text { Gross Domestic Product (GDP)is defined as the } \\
\text { the total market value of all final goods and services } \\
\text { produced in an economy during a given period. }\end{array}$ & Percent & - \\
\hline $\begin{array}{l}\text { Growth rate of } \\
\text { Population }\end{array}$ & $\begin{array}{l}\text { Population growth rate is described as the change in the } \\
\text { the population of a country over a unit period. }\end{array}$ & Percent & - \\
\hline Consumer Price Ind, & $\begin{array}{l}\text { Consumer Price Index (CPI)is used to measure the price } \\
\text { changes in consumer goods. }\end{array}$ & Percent & - \\
\hline
\end{tabular}

\subsection{Empirical Model Specification}

There are two steps in the application of the ARDL technique. First, F-statistic is used to examine the long run association between relevant variables in the model. Second, the coefficients of both long run and short run relationship are estimated and the application of the ARDL method is concluded. General ARDL form of Model is as follows:

$$
\begin{aligned}
& \Delta U N t=\beta 0+\sum_{i=1}^{k 9} \beta 1 i \Delta(U N) t-I+\sum_{i=0}^{k 10} \beta 2 i \Delta(B C P S) t-i+\sum_{i=0}^{k 11} \beta 3 i \Delta(E X R) t-I+\sum_{i=0}^{k 12} \beta 4 i \Delta(G M S) t-i \\
& +\sum_{i=0}^{k 13} \beta 5 i \Delta(B D) t-i+\sum_{i=0}^{k 14} \beta 6 i \Delta(G G D P) t-i+\sum_{i=0}^{k 15} \beta 7 i \Delta(G P O P) t-i \\
& +\sum_{i=0}^{k 16} \beta 8 i \Delta(C P I) t-i+\delta 1(I N F) t-1+\delta 2(B C P S) t-1+\delta 3(E X R) t-1+\delta 4(G M S) t \\
& -1+\delta 5(B D) t-1+\delta 6(G G D P) t-1+\delta 7(G P O P) t-1+\delta 8(C P I) t-1+\mu t
\end{aligned}
$$

Where, $\beta_{0}=$ intercept whereas $\beta_{1}, \beta_{2}, \beta_{3}, \ldots \ldots ., \beta_{8}=$ Short term coefficients of the model and $\delta_{1}, \delta_{2}, \delta_{3}, \ldots \ldots ., \delta_{8}=$ Long term coefficients. $\mu_{\mathrm{t}}=$ stochastic disturbance term.

\subsection{Longrun form of the Model}

$$
\begin{aligned}
& U N t=\lambda 0+\sum_{i=0}^{k 2} \lambda 1 i(I N F) t-i+\sum_{i=0}^{k 2} \lambda 2 i(B C P S) t-i+\sum_{i=0}^{k 3} \lambda 3 i(E X R) t-i+\sum_{i=0}^{k 4} \lambda 4 i(G M S) t-i \\
& +\sum_{i=0}^{k 5} \lambda 5 i(B D) t-i+\sum_{i=0}^{k 6} \lambda 6 i(G G D P) t-i+\sum_{i=0}^{k 7} \lambda 7 i(G P O P) t-i+\sum_{i=0}^{k 8} \lambda 8 i(C P I) t \\
& -i+\mu t
\end{aligned}
$$

\subsection{Shortrun form of the Model}

The short run error correction model of the ARDL technique for our model is presented as: 


$$
\begin{aligned}
& \Delta \mathrm{UNt}=\sigma 0+\sum_{\mathrm{i}=1}^{\mathrm{k} 1} \sigma 1 \mathrm{i} \Delta(\mathrm{UN}) \mathrm{t}-\mathrm{i}+\sum_{\mathrm{i}=0}^{\mathrm{k} 2} \sigma 2 \mathrm{i} \Delta(\mathrm{BCPS}) \mathrm{t}-\mathrm{i}+\sum_{\mathrm{i}=0}^{\mathrm{k} 3} \sigma 3 \mathrm{i} \Delta(\mathrm{EXR}) \mathrm{t}-\mathrm{i}+\sum_{\mathrm{i}=0}^{\mathrm{k} 4} \sigma 4 \mathrm{i} \Delta(\mathrm{GMS}) \mathrm{t} \\
& -\mathbf{i}+\sum_{\mathrm{i}=0}^{\mathrm{k} 5} \sigma 5 \mathbf{i} \Delta(\mathrm{BD}) \mathrm{t}-\mathbf{i}+\sum_{\mathrm{i}=0}^{\mathrm{k} 6} \sigma 6 \mathbf{i} \Delta(\text { GGDP }) \mathrm{t}-\mathbf{i}+\sum_{\mathrm{i}=0}^{\mathrm{k} 7} \sigma 7 \mathbf{i} \Delta(\text { GPOP }) \mathrm{t}-\mathbf{i} \\
& +\sum_{\mathbf{i}=\mathbf{0}}^{\mathbf{k} 8} \sigma \mathbf{i} \mathbf{i} \Delta(\mathrm{CPI}) \mathbf{t}-\mathbf{i}+\boldsymbol{\Psi}(\mathbf{E C M}) \mathbf{t}-\mathbf{i}+\mathbf{\varepsilon t}
\end{aligned}
$$

Here, $\psi$ is the coefficient of the value of ECM.

\section{Empirical Data Analysis}

Data analysis has much significance for econometric estimation and analysis of results. Descriptive analysis is helpful to see the past tendency and predict the future values of the variables.

Table 2: Descriptive Statistics

\begin{tabular}{lllllllll}
\hline & UN & BCPS & EXR & GMS & BD & GGDP & GPOP & CPI \\
\hline Mean & 4.830575 & 23.864 & 1.4341 & 1.625 & 6.818 & 505.09 & 2.628 & 1.363 \\
Std. Dev & 1.869413 & 3.0236 & 0.3396 & 0.038 & 2.304 & 293.97 & 0.475 & 0.405 \\
Median & 5.150500 & 24.085 & 1.4241 & 1.624 & 6.650 & 431.05 & 2.550 & 1.360 \\
Maximum & 8.270001 & 29.791 & 1.9703 & 1.692 & 12.80 & 1266.4 & 3.301 & 2.089 \\
Minimum & 1.654001 & 16.841 & 0.9956 & 1.527 & 2.401 & 100.29 & 2.001 & 0.593 \\
Skewness & 0.020444 & -0.087 & 0.0202 & -0.22 & 0.475 & 1.1548 & 0.081 & -0.01 \\
\hline
\end{tabular}

Source: Calculations are carried out with E-Views 9.

In this study, the Mean of UN is 4.830575 over 43 years which points out that Pakistan has a moderate unemployment rate. The standard deviation of the values of the UN is 1.869413. The mean value of BCPS is 23.684 which points out the very high level of credit that SBP provides to the private sector. The mean value of EXR is 1.4341 showing that there is a relatively moderate level of the exchange rate in Pakistan.

While the standard deviation of EXR is 0.3396 . It indicates that there are very small variations in the exchange rate throughout the concerned period. The mean of GMS is 1.625 . it seems to be a moderate level of the growth rate of money over 43 years in Pakistan. Whereas the measure of the dispersion of GMS is 0.038 telling about the very minimal deviation of GMS from its average value. The mean BD is 6.818 which explains that there is a relatively high budget deficit in the history of Pakistan over 43 years. The value of the standard deviation of $B D$ is 2.304 indicating moderate dispersion from its mean value. The average value of GGDP is 505.09 which shows that the growth rate of Gross Domestic Product (GDP) is high in Pakistan from 1973 to 2015 . The standard deviation of GGDP is 293.97 which points out a very severe deviation from its mean value. The mean value of GPOP is 2.628 showing moderate growth of population in Pakistan over the past 43 years, while its standard deviation is 0.475 indicating fewer variations from the mean. The future values of the variables can be predicted by checking the Stationarity of data.

Table 3: ADF Test Results

\begin{tabular}{cccc}
\hline Variables & Level & 1st Difference & Conclusion \\
\hline UN & -1.6709 & -7.5074 & I $(1)$ \\
BCPS & -2.6071 & -5.5018 & I $(1)$ \\
EXR & 0.5403 & -4.3697 & I $(1)$ \\
GMS & -3.2853 & -6.7859 & I (0) \\
BD & -2.0287 & -7.1705 & I $(1)$ \\
GGDP & 2.01586 & -4.8551 & I $(1)$ \\
GPOP & -1.3661 & -4.2268 & I (1) \\
CPI & 0.3838 & -4.6738 & I (0) \\
\hline
\end{tabular}

Unemployment (UN) is stationary at $1^{\text {st }}$ difference. UN is integrated into $1^{\text {st }}$ order. Its ADF value is -7.50745 at a $1 \%$ level of significance. Hence, it may be written as UN I (1). Bank Credit to Private Sector (BCPS) is stationary at $1^{\text {st }}$ difference. BCPS has the integration of $1^{\text {st }}$ order and its ADF value is -5.50186 at a $5 \%$ level of significance at the intercept. So, it means that BCPS I (1). The exchange rate (EXR) is stationary at $1^{\text {st }}$ difference. EXR is integrated of $1^{\text {st }}$ order and its ADF value is -4.36973 at a $1 \%$ level of significance. So, it might be concluded that EXR I (1). The growth rate of Money Supply (GMS) is integrated into Zero order. GMS is stationary at level. Its ADF value is -3.28539 at a $1 \%$ level of significance with 
intercept. It is also shown as GMS I (0). Budget Deficit (BD) is integrated into $1^{\text {st }}$ order. BD is stationary at $1^{\text {st }}$ difference and its ADF value is -7.1705 at a $5 \%$ level of significance. It may be written as $B D \sim \mathrm{I}(1)$.

The growth rate of Gross Domestic Product (GGDP) and Growth rate of Population (GPOP) are integrated into $1^{\text {st }}$ order. GGDP and GPOP are stationary at $1^{\text {st }}$ difference and their ADF values are -4.8551 and -4.2268 respectively at a $1 \%$ level of significance. It can be expressed as GGDP I (1) and GPOP I (1). Consumer Price Index (CPI) is integrated into Zero order. CPI is stationary at the level and its ADF value is 0.3838 at a $1 \%$ level of significance. It can also be written as CPI I (0). To estimate the long run association between variables we apply the Bound test to check the long run existence of the relationship.

Table 4: Bound test Results

\begin{tabular}{cccc}
\hline Equation & F - statistics & Upper Bound (Critical Value) & Result \\
\hline Model 1 & 3.9578 & 3.17 & Co - integration exists \\
\hline
\end{tabular}

For the model, F-stat is 3.9578 critical value of the upper bond is 3.17 and indicates the existence of the Long run relationship. The results which are obtained by applying the ARDL technique are given in the following table.

Table 5: Long Run Estimates of Model

\begin{tabular}{cccc}
\hline Variables & Coefficients & t- Statistics & Probability \\
\hline BCPS & -0.2743 & -3.4553 & 0.0018 \\
EXR & -6.9501 & -1.2647 & 0.2168 \\
GMS & -1.9285 & -0.3040 & 0.7634 \\
BD & -0.2428 & -2.4468 & 0.0212 \\
GGDP & 0.0083 & 4.6829 & 0.0001 \\
GPOP & -0.2552 & -0.2391 & 0.8128 \\
CPI & -5.1555 & -0.8651 & 0.3946 \\
@TREND & 0.6709 & 3.2069 & 0.0034 \\
\hline
\end{tabular}

Source: Author's Calculations (E-Views 9)

The above table shows that the coefficient of Bank Credit to the Private Sector is negative and its value is 0.2743 . It is statistically significant as shown by its value of probability i-e 0.0018 . The value of the coefficient of BCPS indicates that a $1 \%$ rise in BCPS will reduce unemployment by $0.2743 \%$. It points out that when a central bank provides credit to the private sector in the form of loans, the private sector provides further loans to individuals and private banks and in this way, production, output and investment increase in the economy. In this way, labor could be absorbed, and employment opportunities would be increased leading to a decrease in unemployment. So, BCPS has a negative relationship with unemployment. The results match with Shabbir et al. (2012) and Gocer (2013).

The coefficient of the Exchange Rate is negative, and its value is 6.950153. It is statistically insignificant. The value of the coefficient of EXR shows that a $1 \%$ rise in EXR would result in a decrease in unemployment by 6.9501 percent. Theoretically, when the exchange rate increases in an economy it means that price of foreign currency increases. The domestic currency is depreciated which leads to discouraging the import consumption and domestic production of goods increases leading to increase output and employment as a result unemployment declines. So, this study indicates that there is a negative relationship between the exchange rate and unemployment. The results match with Sarwar (2008). He also concluded that the exchange rate has an indirect relationship with unemployment.

The coefficient of the Growth rate of Money Supply is negative and its value is 1.9285 . The coefficient of GMS shows that if GMS increases by $1 \%$ then accordingly there would be a $1.9285 \%$ reduction in unemployment. If the money supply increases, then it increases the gross domestic product (GDP) firstly. After that with the rise in money supply, aggregate demand also rises and output, employment, and production, as well as investment, also increase which pushes the unemployment level downward. The results bear a resemblance to Shabbir et al. (2012).

The coefficient of Budget Deficit is negative, and its value is 0.2428 with a $0.0212 \mathrm{~m} \mathrm{p}$ value. The value of the coefficient of $B D$ points out that a $1 \%$ increase in $B D$ leads to a decrease in unemployment by 0.001532 percent. The logic behind this is when the 
government faces a budget deficit, then it starts deficit financing through printing new notes, getting external loans, etc. Accordingly, due to the increase in loans, investment also increases in various projects. So, employment opportunities increase, and unemployment decreases in the economy. The results match with Saeidi and Valizadeh (2012).

The coefficient of the Growth rate of Gross Domestic Product is positive and its value is 0.008396 and which is significant. The value of the coefficient of GGDP indicates that a $1 \%$ rise in GGDP would result in a $0.0083 \%$ increase in unemployment. There is a positive relationship between GGDP and unemployment. It is expected that when GDP increases, it raises the aggregate demand, output and employment. But the logic behind the positive relationship between GGDP and unemployment is the rapidly increasing poverty and underutilization of resources. As a result, unemployment increases. The results are similar to those of Umair and Ullah (2013) and Aurangzeb and Asif (2013).

The coefficient of the Growth rate of the Population is negative and its value is 0.2552 . The coefficient value of GPOP specifies that if GPOP increases by $1 \%$ then unemployment decreases by $0.2552 \%$. When the population of a country increases, it means the number of individuals in the country becomes greater than before. In the case of developing countries like Pakistan, which are also labor-abundant countries, the excess population which is unemployed can be absorbed in the production process which implies labor-intensive techniques. In this way, demand for labor in such projects increases leading to a raise the wages and resultantly, unemployment decreases. The results are equivalent to those of Maqbool et al. (2014). The coefficient of the Consumer Price Index is negative and has a value of 5.155588. CPI indicates that if CPI increases by $1 \%$ then it will result in a $5.1555 \%$ reduction in unemployment. CPI has an indirect effect on unemployment. The results resemble Ahmad (2013).

Table 6: Short run estimates of Model

\begin{tabular}{lccc}
\multicolumn{1}{c}{ Variables } & Coefficients & t- Statistics & Probability \\
\hline D(BCPS) & -0.0799 & -1.3621 & 0.1844 \\
D(EXR) & -7.4809 & -1.8155 & 0.0806 \\
D(GMS) & -2.6636 & -0.6708 & 0.5080 \\
D(BD) & 0.0096 & 0.1372 & 0.8918 \\
D(GGDP) & -0.0070 & -3.0601 & 0.0050 \\
D(GPOP) & -1.1598 & -0.7903 & 0.4362 \\
D(CPI) & -6.3235 & -1.1432 & 0.2630 \\
C & 21.6880 & 6.5278 & 0.0000 \\
CointEq (-1) & -0.8402 & -6.3527 & 0.0000 \\
\hline
\end{tabular}

In this model, the value of $\mathrm{R}^{2}$ and Adjusted $\mathrm{R}^{2}$ are 0.92 and 0.90 show $92 \%$ and $90 \%$ variation in unemployment function that is explained by regressors i-e Bank Credit to Private Sector, Exchange Rate, the Growth rate of Money Supply, Budget Deficit, the Growth rate of GDP, the Growth rate of Population and Consumer Price Index. In this model, the DurbinWatson statistics value is 2.42 . It shows that there is no autocorrelation among the variables. Furthermore, F-statistics has a value of 31.20288 which is very strong. So, on the whole, the performance regarding short run estimation of the model seems to be of good quality. The value of CointEq indicates the deviation of estimated quantities from actual ones. Here, the value of CointEq is -0.84 which is statistically significant as pointed out by its probability value which is 0.000 . Both restrictions of minus sign and significance have been satisfied here. The value of Cointegration Eq shows the velocity of modification to re-establish the state of longterm equilibrium. About $84 \%$ of disequilibrium in the previous year is converted into long run equilibrium in the present year. The value of CointEq is highly significant indicating the confirmation that there is a stable long-term association among variables.

Table 7: Diagnostic Tests

\begin{tabular}{ccc}
\hline Test & F - Statistics & Probability \\
\hline Breush - Godfrey Correlation LM Test & 2.038 & 0.151 \\
ARCH Test Heteroskedasticity & 0.0004 & 0.985 \\
Ramsey RESET Test for Model Misspecification & 0.031 & 0.863 \\
\hline
\end{tabular}

Source: Author's calculations (E-Views 9)

From the above table, it is clear that the probability of F-statistics values regarding three tests i-e Breush-Godfrey Correlation LM Test, ARCH Test Heteroskedasticity and Ramsey RESET Test for Model Misspecification for both models is greater than 5\% (0.05) at a $95 \%$ 
confidence interval. It means that there is no autocorrelation in both models, heteroscedasticity does not exist in the models and both models are correctly specified.

\subsection{Stability Analysis}

The stability of the coefficient estimates is tested to measure the appropriateness of the model for policy implications.
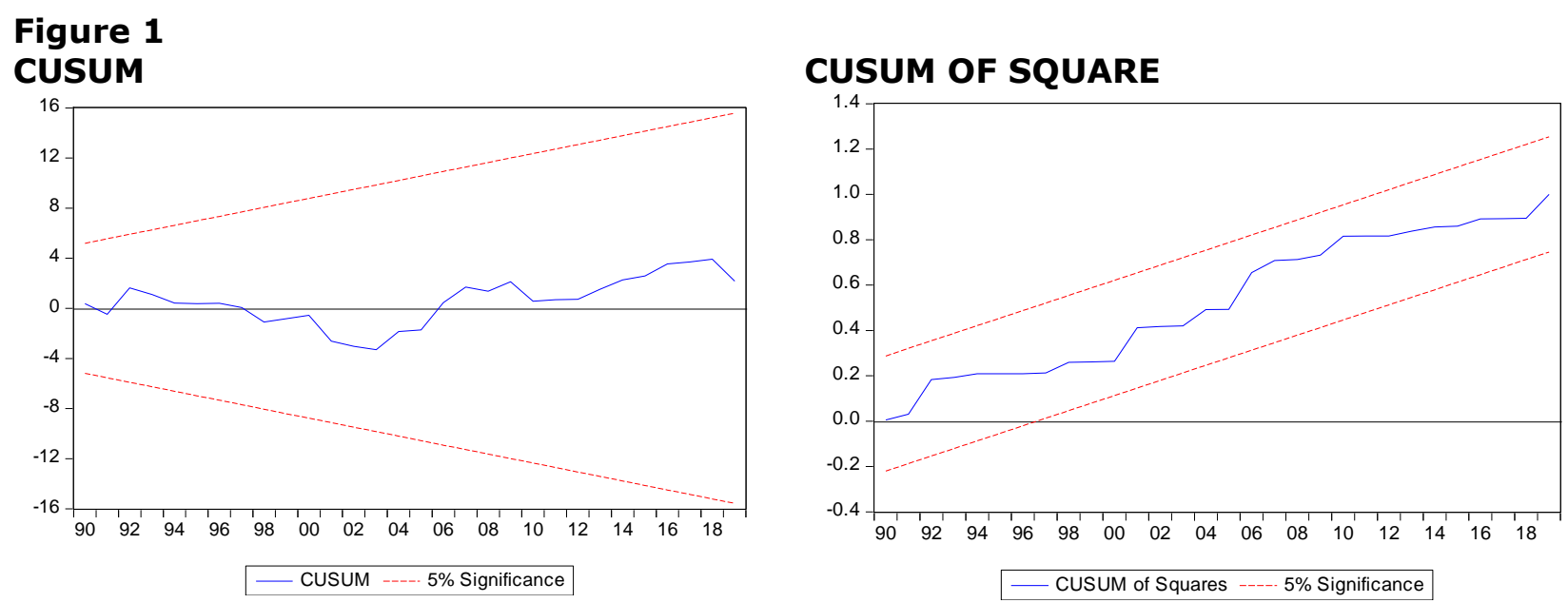

\section{Conclusion and Policy Implications}

The results of the study revealed the effectiveness of monetary policy in different scenarios. The conclusion is that Bank Credit to Private Sector affects unemployment negatively. The exchange rate affects unemployment negatively. Money supply growth has a decreasing effect on unemployment. The signs of most of the coefficients of the variables are the same in the short run and long run while the coefficients of the remaining variables have different signs in the short run and long run. The results indicate that there is a significant and negative relationship between budget deficit and unemployment. GDP growth rate is positively related to unemployment. The population growth rate is negatively related to unemployment. The consumer price index is negatively related to unemployment. Based on the results the State Bank of Pakistan should play an influential role in the determination and derivation of an optimal index which is useful in finding out the latest figures of data which in turn could be used to establish new models based on which useful predictions could be made possible about the unemployment rate. The government of Pakistan should manage a stable exchange rate. The rapidly increasing population should also be controlled so that limited resources in the developing countries could be efficiently and maximally utilized.

\section{References}

Abbritti, M., Boitani, A., \& Damiani, M. (2006). Unemployment, Inflation, and Monetary Policy in A Dynamic New Keynesian Model with Hiring Costs.

Ahmad, F. (2013). The Effect of Oil Prices on Unemployment: Evidence from Pakistan Business and Economic Research Journal, 4(1), 43-57.

Aqil, M., Qureshi, M. A., Ahmed, R. R., \& Qadeer, S. (2014). Determinants of unemployment in Pakistan. International Journal of Physical and Social Sciences, 4(4), 676.

Alexius, A., \& Holmlund, B. (2007). Monetary Policy and Swedish Unemployment Fluctuations. Economic Discussion Paper, (2007-34).

Altavilla, C., \& Ciccarelli, M. (2009). The Effects of Monetary Policy on Unemployment Dynamics Under Model Uncertainty; Evidence from the United States and the euro area. Journal of Money, Credit and Banking, 41(7). 1265-1300.

Ahmad, A., \& Khan, F. (2018). Investigating the determinants of youth unemployment in Pakistan. Pakistan Journal of Humanities \& Social Science Research, 1(1), 1-12.

Aurangzeb, D. \&Asif, K. (2013). Factors Affecting Unemployment: A Cross-Country Analysis. International Journal of Academic Research in Business and Social Sciences, 3(1), 219.

Berentsen, A. Menzio, G., \& Wright, R. (2008). Inflation and Unemployment in the Long Run. (No. w13924). National Bureau of Economic Research.

Carlson, K. M. (1978). Inflation, Unemployment, and Money: Comparing the Evidence from Two Simple Models. Federal Reserve Bank of St. Louis Review, 60, 2-6. 
Cashell, B.W. (2004). Inflation and Unemployment: What Is the Connection? Federal Publications, 180.

Chicheke, A. (2009). Monetary Policy, Inflation, Unemployment, and the Phillips Curve in South Africa (Doctoral Dissertation, University of Fort Hare).

Djivre, J.\& Ribon, S. (2003). Inflation, Unemployment, The Exchange Rate and Monetary Policy In Israel, 1990-99: A Svar Approach. Israel Economic Review, 1(2).

Epstein, G. (2007). Central Banks, Inflation Targeting and Employment Creation, (No. 2007/02). International Labor Office.

Galbraith, J.K., Giovannoni, O.G., \& Russo, A.J. (2007). The Fed's Real Reaction Function, Monetary Policy, Inflation, Unemployment, Inequality and Presidential Politics.

Gocer (2013). The relation between Bank Loans and Unemployment in the European Countries. European Academic Research, Vol. 1; ISSN: 2286-4822.

Hanif, M. N. (2014). Monetary policy experience of Pakistan.

Khurshid, U. (2014). Monetary Policy \& Its Success in Developing Economies; A Case Review for Pakistan: Interdisciplinary Journal of Contemporary Research in Business, May 2014, Vol 6, No.1.

Maqbool, M. S., Sattar, T. M. A., \& Bhalli, M. N. (2013). Determinants of unemployment: Empirical evidence from Pakistan. Pakistan Economic and Social Review, 51(2), 191.

Mahmood, H., Waheed, A., \& Khalid, S. (2017). The impact of monetary strategies on economic growth: an empirical analysis for Pakistan. Asian Journal of Empirical Research, 7(10), 260-268.

N' Diaye, P.M.B., \& Laxton, M.D. (2002). Monetary Policy Credibility and The UnemploymentInflation Trade-Off: Some Evidence From 17 Industrial Countries (No. 2-220). International Monetary Fund.

Saeidi and valizadeh (2012). Impact of Budget Deficit on Inflation and Unemployment in Iran's Economy. Journal of Basic and Applied Research; ISSN: 2090-4304.

Sarwar, M. D. H. S. (2008). Impact of Foreign Direct Investment on Employment Level in Pakistan: A Time Series Analysis.

Shabbir, G., Anwar, S., Hussain, Z., \& Imran, M. (2012). Contribution of financial sector development in reducing unemployment in Pakistan. International Journal of Economics and Finance, 4(1), 260.

Subhan,Q.A.,\& Hayat, M.A.(2008).Impact Of Price Stability On Unemployment and Economic Growth in Pakistan (An Econometric Approach). Department of Management Sciences, Bahria University, Islamabad, Pakistan.

Umair, M., \& Ullah, R. (2013). Impact of GDP and Inflation on Unemployment Rate: A Study of Pakistan Economy in 2000-2010.International Review of Management and Business Research, 2(2), 388. 